\title{
Tree Diversity, Initial Litter Quality, and Site Conditions Drive Early- Stage Fine-Root Decomposition in European Forests
}

\author{
Janna Wambsganss, ${ }^{1,3 *} \odot$ Grégoire T. Freschet, ${ }^{2}$ Friderike Beyer, ${ }^{1}$ \\ Jürgen Bauhus, ${ }^{1}$ and Michael Scherer-Lorenzen ${ }^{3}$
}

Chair of Silviculture, Faculty of Environment and Natural Resources, University of Freiburg, Tennenbacherstr. 4, 79106 Freiburg, Germany; Station d'Ecologie Théorique et Expérimentale, CNRS, Université Toulouse III, 09200 Moulis, France; Faculty of Biology, University of Freiburg, Schaenzlestrasse 1, 79104 Freiburg, Germany

\begin{abstract}
Decomposition of dead fine roots contributes significantly to nutrient cycling and soil organic matter stabilization. Most knowledge of tree fine-root decomposition stems from studies in monospecific stands or single-species litter, although most forests are mixed. Therefore, we assessed how tree species mixing affects fine-root litter mass loss and which role initial litter quality and environmental factors play. For this purpose, we determined fine-root decomposition of 13 common tree species in four European forest types ranging from boreal to Mediterranean climates. Litter incubations in 315 tree neighborhoods allowed for separating the effects of litter species from environmental influences and litter mixing (direct) from tree diversity (indirect). On average, mass loss of mixedspecies litter was higher than those of single-species litter in monospecific neighborhoods. This was mainly attributable to indirect diversity effects, that is, alter-
\end{abstract}

Received 19 May 2021; accepted 4 November 2021;

published online 20 December 2021

Supplementary Information: The online version contains supplementary material available at https://doi.org/10.1007/s10021-02100728-3.

Author's Contribution: MSL and JB conceived the study and acquired funding for the project. All authors designed the study. JW carried out data collection, performed the analysis, and drafted the manuscript. All authors discussed and interpreted the results and contributed to the writing of the manuscript.

*Corresponding author; e-mail: janna.wambsganss@gmail.com ations in microenvironmental conditions as a result of tree species mixing, rather than direct diversity effects, that is, litter mixing itself. Tree species mixing effects were relatively weak, and initial litter quality and environmental conditions were more important predictors of fine-root litter mass loss than tree diversity. We showed that tree species mixing can alter fine-root litter mass loss across large environmental gradients, but these effects are context-dependent and of moderate importance compared to environmental influences. Interactions between species identity and site conditions need to be considered to explain diversity effects on fine-root decomposition.

Key words: absorptive fine roots; environmental gradient; functional trait diversity; site-specific litter; SoilForEUROPE; species identity; standard litter; tree species mixing.

\section{HighLIGHTS}

- Effects of tree diversity on fine-root litter mass loss across Europe were studied

- Tree diversity accelerated overall fine-root litter mass loss

- Initial litter quality and environmental conditions further affected fine-root decomposition 


\section{INTRODUCTION}

The decomposition of plant litter is one of the key processes influencing carbon $(\mathrm{C})$ and nutrient cycling and thereby crucial for overall ecosystem functioning (Swift and others 1979). Drivers of decomposition rates have mainly been identified for aboveground litter, despite the substantial contribution of fine-root litter to total plant litter inputs (for example, Freschet and others 2013), soil organic matter formation (Angst and others 2021), and nutrient availability in soils (Hobbie 2015). Necromass of both fine roots and fungi, which are often associated with roots, can also contribute to the stabilization of soil organic matter, thereby possibly increasing $\mathrm{C}$ residence time in soils (Cotrufo and others 2013; Adamczyk and others 2019). In particular, the most distal root orders have relatively low life spans (McCormack and others 2012) and yet may decompose slower than higherorder roots (for example, Xiong and others 2013). Hence, fine roots may play a significant role in soil $C$ sequestration. In addition, fine-root turnover is very important for nutrient cycling (Jackson and others 1997; Gordon and Jackson 2000). Owing to lower nutrient resorption, fine-root nutrient concentrations at senescence are likely higher than in freshly shed leaves (Brant and Chen 2015). In addition, trees may allocate a greater share of biomass to roots than to foliage (Reich and others 2014). This further highlights the crucial role of tree root litter for $\mathrm{C}$ and nutrient cycling in forests.

Several studies have shown that leaf and root litter can decompose at different rates (Vivanco and Austin 2006; Hobbie and others 2010; Freschet and others 2013). Their decomposition rates are controlled by distinct factors, and particularly, lignin appears to play different roles in leaf and root litter decomposition (Hobbie and others 2010; Sun and others 2018). Contrasting drivers consequently prevent a simple transfer of results from leaf litter decomposition studies to those of fine-root litter. Moreover, inconsistent results regarding the major controls of fine-root decomposition have been reported. Climatic variables, including mean annual temperature (MAT) and precipitation (MAP), have often been found to strongly affect fine-root decomposition (for example, Zhang and others 2008; See and others 2019). Moreover, initial litter quality (particularly root nitrogen $(\mathrm{N})$, calcium (Ca), and lignin concentrations) has also been shown to be a strong determinant of fine-root litter decomposition by some (Zhang and others 2008; Zhang and Wang 2015; See and others 2019), yet, not by others (Hobbie and others 2010; Sun and others 2013).

Most studies of root litter decomposition dynamics have concentrated on single species, even though the majority of the world's natural forests are mixed (Bauhus and others 2017), and so is their litter. Moreover, current management strategies increasingly focus on promoting tree species mixtures (Bauhus and others 2017), as they can enhance the provision of ecosystem services compared to their monospecific counterparts (reviewed by Scherer-Lorenzen 2014).

Tree diversity may alter litter decomposition rates via several direct and indirect effects (Hector and others 2000; Gessner and others 2010). Direct interaction effects occur when litter properties of at least one species in mixture alter decomposition rates in litter of other species. These nonadditive effects, which have been observed in $15 \%$ of litter mixtures globally (Porre and others 2020), can be either synergistic (accelerate) (for example, Scherer-Lorenzen 2008) or antagonistic (decelerate decomposition) (for example, Grossman and others 2020). Synergistic effects may stem from complementary resource use among detritivores (for example, Vos and others 2013), nutrient transfer from rich to poor litter (for example, Schimel and Hättenschwiler 2007) through fungal transport (Tiunov 2009) or leaching (McTiernan and others 1997), or more favorable microclimatic conditions (Makkonen and others 2013; Liu and others 2020) in mixed vs. single-species litter. Antagonistic effects may stem from the presence of inhibitory secondary compounds such as condensed tannins (Hättenschwiler and Vitousek 2000; Hättenschwiler 2005), via the inhibitory effect of increased $\mathrm{N}$ availability on the synthesis of lignolytic enzymes by microorganisms or the recombination of $\mathrm{N}$ with partly decomposed compounds (Berg 2014), and also altered microclimatic conditions (Makkonen and others 2013). These interactions are under the influence of initial species' chemical and physical litter traits (Liu and others 2020). As such, a higher dissimilarity in litter traits among species may lead to stronger synergistic or antagonistic mixing effects, as shown for leaf litter (Makkonen and others 2013) or cellulose paper (Joly and others 2017). Yet, litter trait dissimilarity has not always been found to affect mixed leaf litter decomposition (Barantal and others 2011; Lin and Zeng 2018; Porre and others 2020), and functional trait identity was further suggested to play an important role (Grossman and others 2020), in some cases even more than trait dissimilarity (Schindler and Gessner 2009; Frainer and others 
2015). Whether chemical or physical trait dissimilarity in fine roots affects their decomposition in mixtures has not been tested so far.

In addition, tree species diversity at the location of litter incubation may indirectly affect root litter decomposition. For instance, alterations in canopy structure can affect understory species composition (Leuschner and Ellenberg 2017), forest floor temperature and moisture (Joly and others 2017) and edaphic properties, such as soil $\mathrm{pH}$ or texture (Prescott and Grayston 2013; Scheibe and others 2015; Dawud and others 2016). In turn, these influence soil fauna (Korboulewsky and others 2016), microbial communities (Scheibe and others 2015), or priming effects via root exudation (Zwetsloot and others 2020), consequently affecting decomposition. To date, only relatively few studies have examined such indirect diversity effects (for example, Joly and others 2017). Yet, the separation of direct from indirect effects is a prerequisite for identifying the prevailing drivers of litter decomposition at small scales (that is, litter characteristics versus altered decomposition environment) and would thereby greatly improve our mechanistic understanding of diversity effects.

Globally, the occurrence, strength, and direction of diversity effects on leaf litter decomposition are still highly debated, as illustrated by several reviews and meta-analyses (Gartner and Cardon 2004; Hättenschwiler 2005; Gessner and others 2010; Kou and others 2020; Liu and others 2020; Porre and others 2020), potentially due to a predominance of studies suggesting rather than testing the mechanisms behind these effects. Nonetheless, as described above, a range of studies have demonstrated the existence of causal links between leaf litter traits and nonadditive effects (for example, Schimel and Hättenschwiler 2007); Joly and others 2017). Such a mechanistic understanding remains to be extended to the belowground decomposition of fine-root mixtures.

The majority of studies assessing diversity effects on fine-root litter decomposition comes from grasslands and report both positive and negative effects of species mixing on mass loss (Chen and others 2017a; Prieto and others 2017). The three studies on fine-root litter mixing in forests observed no effects on fourth- and fifth-order roots in a tropical tree diversity experiment (Guerrero-Ramírez and others 2016), negative effects in a subtropical forest (Li and others 2018), and positive effects in a subtropical plantation (Jiang and others 2019). Based on these studies, no mechanistic process can be identified as driving the nonadditive effects of fine-root litter decomposition in mixtures.
Inconsistent methodologies (for example, variations in mesh size, incubation time, or root functional type) can limit the comparability of studies (Liu and others 2020). A major constraint of root decomposition studies may be the lack of differentiating between fine-root orders, which are known to vary in chemical and physical properties (for example, Pregitzer 2002; Beyer and others 2013) and thus also in decomposition patterns (Sun and others 2013, 2016; Xiong and others 2013) and thereby have different impacts on $\mathrm{C}$ and nutrient cycling.

To address the mentioned knowledge gaps, we quantified fine-root litter mass loss of 13 common tree species in relation to tree species diversity, initial fine-root traits, and micro- and macroenvironmental conditions in four European forest types ranging from boreal to Mediterranean climate. Because the very fine roots contribute significantly to soil litter inputs (McCormack and others 2015), we focus on the first three root orders. We hypothesized that (i) fine-root mass loss increases with tree species diversity, with (ii) direct diversity effects through litter mixtures being stronger determinants than (iii) indirect effects through alterations of the decomposition environment. In addition, we hypothesized that (iv) a higher functional dispersion in initial litter traits enhances diversity effects on root litter mass loss. To assess the relative importance of these diversity effects, we further investigated the influence of initial litter traits and site conditions on fine-root decomposition.

\section{MeThODS}

\section{Study Design}

We used a subset of study sites and plots of the FunDivEurope project, which studies the effect of tree diversity on ecosystem functioning in mature European forests (Baeten and others 2013). Here, we selected monospecific and three-species mixed plots in four study sites comprising boreal (Finland), hemiboreal (Poland), mountainous beech (Romania), and Mediterranean thermophilous forest (Italy). Each site had between nine and nineteen $30 \times 30 \mathrm{~m}$ plots with a pool of three to five site-specific target species (Table S1). Three of the 13 target species occurred in more than one study site (Betula pendula in Finland and Poland, Picea abies in Finland, Poland, and Romania, and Pinus sylvestris in Finland and Poland). In total, 21 different tree species combinations were studied across all plots and sites. Plot selection was made 
following predefined criteria, including evenness of species proportions (based on the target species' basal areas, which made up more than $90 \%$ of the plot's total basal area), stand age and density, and site factors including soil characteristics, topography, and former management type. Besides establishing a gradient in tree species diversity, abiotic and biotic conditions were kept as homogeneous as possible during plot selection to minimize the influence of confounding factors (Baeten and others 2013). Within each plot, we selected five subplots at the level of tree neighborhoods following the triplet design of Vivanco and Austin (2008). These triplets consisted of a triangle shaped by three trees, of either the same species in monospecific stands or different tree species in mixed-species plots. For these triplets, we aimed at selecting healthy, dominant, or co-dominant trees of similar dimensions, and the five triplets were ideally evenly distributed across the plot. For more details on the selection of the triplets, see Wambsganss and others (202la, b).

At each triplet, a set of litter bags filled with different litter species was deployed in the center of the triangle. See Figure 1 for a description of the design and composition of litter bags to test the four hypotheses. We incubated site-specific root litter, that is, of species occurring in the triplet, and in addition two standard litter species, that is, Pinus sylvestris and Carpinus betulus, to clearly separate environmental influences from initial litter quality effects. The standard litter species were deployed at all sites and selected owing to their dissimilarity in root traits (thick- vs thin-rooted, different chemical composition, and mycorrhization intensity).

\section{Root Collection and Preparation of Litter Bags}

Root material of the 13 species was collected in fall 2017 from the surface soil (top $15 \mathrm{~cm}$ ) of pure stands in Southwest Germany (that is, the midpoint of our pan-European latitudinal gradient) and Italy (for the species not present in Germany, that is, Ostrya carpinifolia, Quercus ilex, and Q. cerris). We sampled additional roots for each species by tracing roots back to tree stems and used them as reference material for further sorting of roots. To extract roots, soil was washed carefully over a sieve cascade in the laboratory. In contrast to leaf litter decomposition studies, where freshly senesced or shed leaves are typically used, fine-root decomposition experiments inevitably include fresh fine roots because of difficulties associated with sam- pling recently senesced, but yet undecomposed roots (for example, Hobbie and others 2010).

After removing roots from soil, we separated fresh fine roots of the target species according to their function into the first three-order (absorptive) roots and higher-order (transport) roots $2 \mathrm{~mm}$ according to McCormack and others (2015). Dead roots (hollow, dark stele, breakable, not elastic) were discarded. Representative subsamples of live absorptive and transport roots were taken and kept frozen $\left(-20^{\circ} \mathrm{C}\right)$ until trait analyses could be performed. Roots of each target species were air-dried to constant mass and stored at room temperature. Before filling the litter bags with dried roots, the root samples of each species were well mixed, and three subsamples of $50 \mathrm{mg}$, respectively, were taken to determine the initial moisture content (oven-dried at $105^{\circ} \mathrm{C}$ for $48 \mathrm{~h}$ ) and subsequent ash content (in a muffle furnace at $850^{\circ} \mathrm{C}$ for $2 \mathrm{~h}$ ). The samples' air-dry moisture content was on average $10.2 \pm 0.15 \%$ and ash content on average $9.04 \pm$ $0.09 \%$. In total, 1,330 litter bags were filled with $50 \mathrm{mg}$ each. For the three-species mixture bags, each species represented one-third of that mass. Mesh bags consisted of precision woven synthetics monofilament fabrics (Sefar Nitex) with a mesh size of $100 \mu \mathrm{m}$, which only allows small organisms, including fungal hyphae, to enter the bags but excludes roots and larger soil fauna. Hence, this study focused on microbial decomposition, which is presumably more important in soils than for aboveground leaf litter decomposition (Silver and Miya 2001). All bags were labeled, and those placed at the same microsite were tied together with a wire while ensuring a distance of several centimeters between bags.

\section{Root Incubation and Harvest}

Litter bags were incubated at the beginning of spring 2018 at different dates along the NorthSouth gradient (Table S1). Bags were moistened before inserting them vertically in the upper $10 \mathrm{~cm}$ of the topsoil (below the organic horizon) by creating an incision in the soil using a shovel and gently pressing the soil around the bag. The closed incision was covered again with on-site leaf litter. Litter bags were retrieved after about 365 days and subsequently dried at $40^{\circ} \mathrm{C}$. The adhering soil was carefully brushed off, and hyphae growing inside the bags were removed. To account for mineral particle contamination, the ash content was determined for each root litter sample incubated at the Italian and Romanian site, which had high soil clay contents (Table S1). The air-dried mass of each 

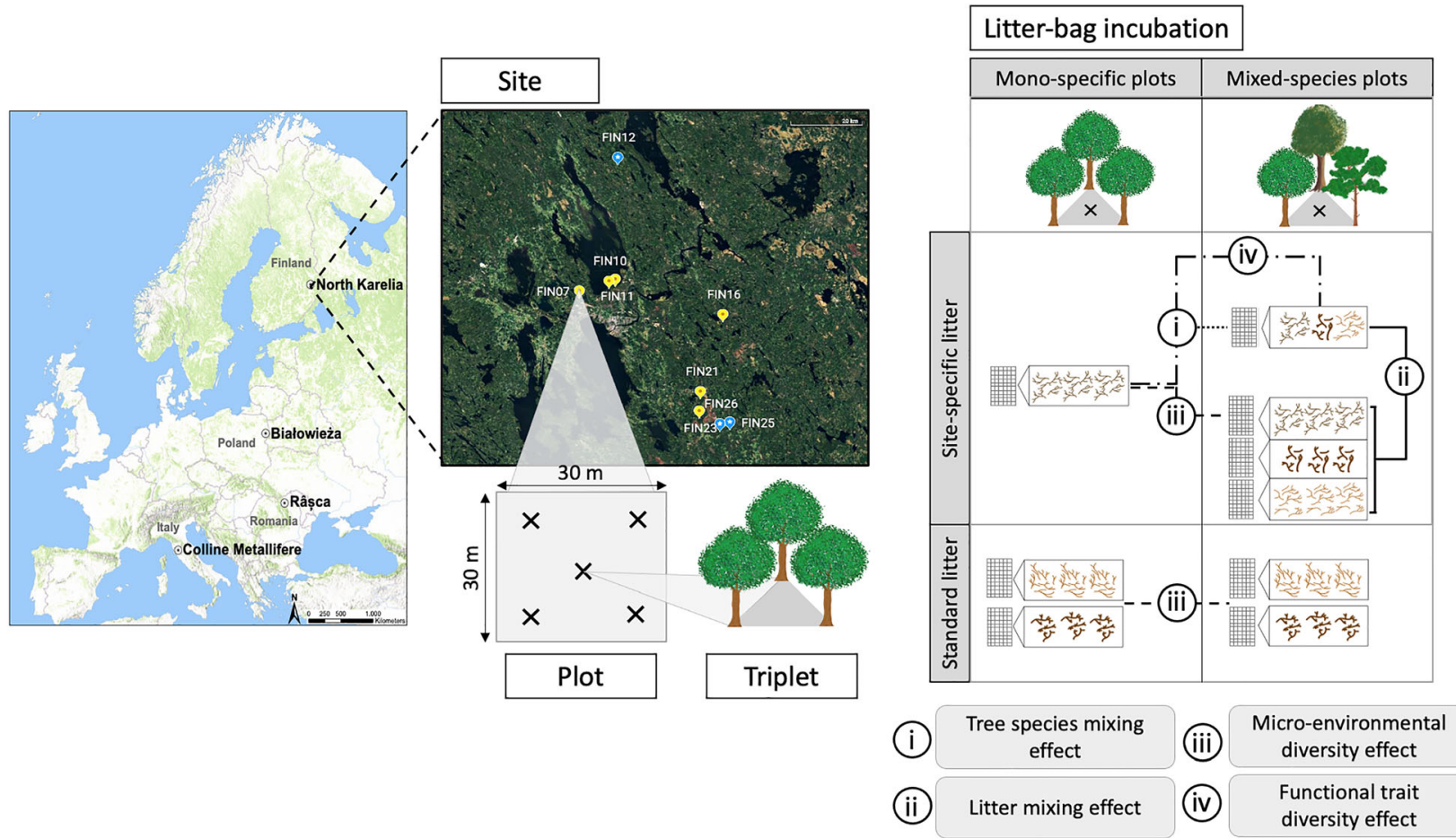

Figure 1. Illustration of the study design for testing diversity effects on root litter mass loss after one year of incubation. For each of the overall 62 plots across the four sites, five tree triplet microsites were selected. In monospecific stands, these triplets consisted of three tree individuals of the same species, whereas in the mixed plots, three different tree species shaped a triplet. To test tree species mixing effects (Hypothesis i), site-specific fine-root litter matching the canopy was incubated in the center of each of the five triplets, and mass loss was compared between both diversity levels. To test litter mixing effects (Hypothesis ii), single-species root litter of the component species was also incubated in mixed neighborhoods and compared with mixed litters in the same stand (homogeneous environmental conditions). The site-specific singlespecies litter in mixed and monospecific stands was also used to test the microenvironmental diversity effect (Hypothesis iii). In addition, two standard litter species, that is, Carpinus betulus and Pinus sylvestris, were deployed in single-species litter bags in both monospecific and mixed stands to test Hypothesis iii. The role of functional trait diversity in fine-root litter decomposition (Hypothesis iv) was assessed for overall effects.

sample was corrected for initial water and mineral content. For sites in Finland and Poland (sandy soils), we only corrected for initial water content, as mineral particle contamination could be excluded (which was confirmed by quantifying the ash content of a subset of representative samples). We quantified decomposition as mass loss in \% of the initial mass after one year of incubation.

\section{Root Trait Selection and Measurements}

Based on a literature search, we considered the following traits as most crucial for the decomposition of the most distal fine-root orders: root $\mathrm{C} / \mathrm{N}$ ratio as a proxy for litter quality (Silver and Miya 2001; Zhang and Wang 2015), ectomycorrhizal (EcM) colonization intensity (Langley and others 2006), root N, Ca (Silver and Miya 2001; Zhang and Wang 2015), K (Chen and others 2017b), Mg (Berg 1984), Mn (Keiluweit and others 2015), and
P concentrations (See and others 2019), root diameter (Hobbie and others 2010), and root tissue density (RTD, Jiang and others 2020). Five representative subsamples were used to quantify initial functional traits for each root species of the live or air-dried fine-root material (Table S2). Healthy tips and tips colonized by EcM were visually identified and counted under a binocular to determine root tip density (total number of tips per root length, $\mathrm{n} \mathrm{cm}^{-1}$ ) and EcM colonization rate (proportion of infected vs total number of tips in \%). Infected tips were identified for 12 of the 13 tree species based on the presence of a fungal sheath (Acer pseudoplatanus associates with arbuscular mycorrhizae). The first three-order fine-root samples were scanned in water with a flat-bed scanner (resolution $800 \mathrm{dpi}$ ). Scans were analyzed with the software WinRhizo (Regents Instruments, Quebec, Canada, 2009) to obtain root length, area, volume, and diameter. Root volume and (average) diameter 
values were recalculated based on individual diameter classes to avoid bias resulting from the global values calculated by WinRhizo assuming constant root diameter (Freschet and others 2020). Samples were dried $\left(40{ }^{\circ} \mathrm{C},>72 \mathrm{~h}\right)$ and weighed. For chemical analysis, the dried root samples were ground to fine powder with a Retsch MM400 mixer mill (Retsch $\mathrm{GmbH}$, Germany). Total organic $\mathrm{C}$ and $\mathrm{N}$ in this homogenized material were determined by dry combustion with a Vario El Cube Elementar analyzer (Elementar Analysesysteme GmbH, Germany). To measure initial macronutrient ( $\mathrm{N}, \mathrm{P}, \mathrm{K}$, $\mathrm{Ca}, \mathrm{Mg}$ ) and micronutrient $(\mathrm{Mn}, \mathrm{Cu}, \mathrm{Zn})$ concentrations, $75 \mathrm{mg}$ of root material was mixed with $1.5 \mathrm{ml}$ distilled $\mathrm{H}_{2} \mathrm{O}, 1.5 \mathrm{ml} \mathrm{H}_{2} \mathrm{O}_{2}(30 \%)$, and $3 \mathrm{ml}$ $\mathrm{HNO}_{3}(>65 \%)$. Microwave digestion was applied for 12 min (CEM Discover SP-D, CEM Corporation, USA), and subsequently, solutions were filtered and diluted with distilled $\mathrm{H}_{2} \mathrm{O}$ to $25 \mathrm{ml}$. An optical emission spectrometer with inductively coupled plasma (ICP-OES, SPECTROBLUE, SPECTRO Analytical Instruments $\mathrm{GmbH}$, Germany) was used to determine element concentrations.

\section{Environmental Data}

Macroclimate, soil, and forest floor data were obtained from the FunDivEurope database (https://data. botanik.uni-halle.de/fundiveurope). Soil parameters were measured at the plot level in 2012 (Dawud and others 2017), while forest floor properties were derived from samples taken in 2017 at the same subplots used in this study (Gillespie and others 2021). Microclimate variables were measured throughout the incubation period, with recordings every $15 \mathrm{~min}$ using TMS-4 data loggers (TOMST, Prague, Czech Republic). These loggers were installed in each plot center, measuring soil temperature, soil moisture (at $10 \mathrm{~cm}$ depth), and air temperature (1 $\mathrm{m}$ above the ground). Mean values for the year and the growing season (daily mean temperatures $>5{ }^{\circ} \mathrm{C}$ ) were calculated for each plot. For soil moisture, daily minimum values were used instead of means, as water accumulated around the sensors after rain events, possibly distorting mean values.

\section{Data Analysis}

All statistical analyses were performed using $\mathrm{R}$ version 3.5.1. (R Core Team 2018), and significance levels were set at $P=0.05$.

\section{Diversity Effects}

To assess diversity effects on root decomposition, we calculated the proportional deviation from the expected mass loss, according to Loreau (1998). We did this for (i) (overall) tree species mixing effects, (ii) direct litter mixing effects, and (iii) indirect diversity effects on the microenvironment.

The following equation was used to quantify these diversity effects at the plot level (Loreau 1998; Palmborg and others 2005):

$$
D_{\text {mix }}=\frac{O-E}{E}
$$

where $D_{\text {mix }}$ is calculated, respectively, as:

(i) Tree species mixing effects $(=$ combined direct and indirect effects)

$O$ is the observed mass loss of mixed-species litter located in tree species mixtures, and $E$ equals the expected mass loss of mixed-species litter, derived from the mean of mass loss of the component single-species root litter in monospecific plots.

(ii) Litter mixing effects (=direct effects)

where $O$ is the observed mass loss of mixed-species litter located in tree species mixtures and $E$ equals the expected mass loss of mixed-species litter, derived from the mean of mass loss of the component single-species root litter in mixed plots.

(ii) Microenvironmental diversity effects (=indirect effects)

where $O$ is the observed mass loss of single-species litter located in tree species mixtures and $E$ equals the expected mass loss based on the component single-species root litter mass loss in monospecific plots.

In cases in which $D_{\text {mix }}$ significantly differs from zero, effects are nonadditive; when $D_{\text {mix }}$ does not differ from zero, effects are additive. We used Wilcoxon signed-rank tests or t-tests to test whether $\mathrm{D}_{\text {mix }}$ significantly differed from zero. Nonparametric tests were used in case data distribution was not normal, even after transformation.

\section{(iv) Functional trait dissimilarity}

To quantify dissimilarity in initial fine-root traits for mixed-species litter, we used the functional dispersion (FDis) index by Laliberté and Legendre (2010) based on species' mean initial trait values ( $R$ package, $F D$, Laliberté and others (2014)). First, we calculated multidimensional trait divergence of a combination of eight morphological, chemical, and microbial initial root traits including root tissue density (RTD), specific root length (SRL), EcM colonization intensity, $\mathrm{Ca}, \mathrm{K}, \mathrm{N}, \mathrm{Mg}$, and $\mathrm{Mn}$. These traits were selected after testing correlation coefficients among the measured initial root traits (Fig- 
ure S1). We also calculated an alternative FDis index replacing initial RTD by $\mathrm{P}$ and $\mathrm{N}$ by $\mathrm{C} / \mathrm{N}$. We additionally quantified FDis indices for single traits. To account for the nested study design, we used linear mixed-effects models (LMMs) to test whether diversity effects were driven by FDis indices ( $R$ packages LME4, Bates and others 2015). In case of violations of the LMMs' assumptions, response variables were transformed ( $\mathrm{R}$ package bestNormalize, Peterson, 2017). Marginal and conditional $\mathrm{R}^{2}$ values for all models were retrieved using the $R$ package r2glmm (Jaeger 2017). Fixed effects were scaled, and collinearity among variables was tested using variance inflation factors (vif), considering vif $>5$ as threshold for collinearity (R package car, Fox and Weisberg 2011). All models were fit with random slopes and intercepts and nested random effect structures. Here, we fitted FDis of single traits and FDis of all eight traits combined, respectively, in response to tree species mixing effects of sitespecific litter (for details on the model structures, see caption of Table S3). Model selection using dredge and subsequently averaging using mod.avg were employed to obtain the most parsimonious model (R package MuMln, Bartoń 2019). These functions allow for a ranking of all possible models based on the lowest Akaike information criteria (AIC) and subsequently select a subset of models with a $\triangle$ AIC $<4$ based on a $95 \%$ confidence set, which are then averaged (Burnham and Anderson 2002).

\section{Relative importance of diversity, initial litter quality, and site conditions}

Mean mass loss rates of each species were calculated based on data from single-species litter bags. To test whether mean mass loss differed among sites, Kruskal-Wallis and post hoc tests (Dunn) were used.

Influence of Initial Root Traits on Mass Loss (SiteSpecific Litter) The role of initial root traits on fine-root litter mass loss was assessed using sitespecific root litter data, that is, root litter bags filled with litter material matching the triplet tree composition (single-species litter bags in monospecific triplets and mixed-species litter bags in mixed triplets). We used LMMs to test selected variables (see previous section on Root trait selection and measurements) as predictors of the fine-root mass loss after checking variance inflation. Subsequently, RTD, root $\mathrm{N}$, and root diameter were excluded from the model owing to their higher vif factors. Model selection and averaging were used to obtain the most parsimonious model. Subsequently, a synthesis model including all significant predictors (Table S5) and tree species diversity was fitted to determine the relative importance of predictor variables.

The final model for the site-specific litter was as follows:

$$
\begin{aligned}
& \text { orderNorm (mass loss) } \sim \text { tree diversity } \\
& \quad+\text { initial root } \mathrm{C} / \mathrm{N}+\text { initial root } \mathrm{P} \text { conc. } \\
& \quad+\text { initial root } \mathrm{Mg} \text { conc. }+ \text { random }(\text { Site } ; \text { Plot })
\end{aligned}
$$

Influence of Environmental Conditions on Mass Loss (Standard Litter) The role of site conditions on fine-root litter mass loss was tested with LMMs using the standard litter data, as this dataset allowed us to disentangle the effects of substrate quality from environmental conditions on litter mass loss.

For the topsoil $(\mathrm{pH}$, bulk density, $\mathrm{C} / \mathrm{N}$, clay \%) and forest floor ( $\mathrm{P}$, lignin, mass, $\mathrm{N}$ ) variables, we performed a principal component analysis (PCA) to summarize the variables and prevent model overfitting (Figure S2). The respective axes of the two PCAs were extracted and tested as explanatory variables in the respective models (see below). Soil PCA axis 1 indicates a physicochemical gradient from sandy, acidic soils to denser, clay-rich, and less acidic soils. Soil PCA axis 2 represents a gradient ranging from low to high soil fertility, represented by high and low soil $\mathrm{C} / \mathrm{N}$, respectively. Forest floor PCA axis 1 describes a gradient of properties linked to herbivory defense strategies, ranging from the dominance of chemical defense indicated by high phenol and lignin concentrations to more structural/physical strategies indicated by high lignin concentrations. Forest floor PCA axis 2 represents a gradient from more favorable, that is, higher forest floor $\mathrm{P}$ and $\mathrm{N}$, to more adverse conditions for decomposition, that is, low forest floor $\mathrm{P}$ and N. For the microclimate variables, we considered mean annual soil temperature and moisture and for macroclimate variables MAT and MAP.

To avoid model overfitting, a hierarchical modeling approach was used following Joly and others (2017). In a first step, we separately tested the effects of the selected soil and forest floor PCs and macroclimatic and microclimatic variables on litter mass loss. Hence, we fitted three separate models, that is, (i) soil and forest floor model, (ii) microclimate model, and (iii) macroclimate model. We again applied model selection and averaging and kept the individual models' significant predictor variables (Tables S6-S8). 
Consequently, the final model for the standard litter was as follows:

$$
\begin{aligned}
& \text { Sqrt }(\text { mass loss }) \sim \text { tree diversity }+ \text { species } * \text { soil PC } 1 \\
& \quad+\text { species } * \text { soil PC } 2+\text { species } * \text { forest floor PC } 2 \\
& + \text { species } * \text { MAT }+ \text { species } * \text { MAP } \\
& \quad+\operatorname{random}(\text { Site } ; \text { Plot } ; \text { Triplet })
\end{aligned}
$$

Model selection and averaging were applied again to find the most parsimonious model. To estimate the relative importance of each fixed effect, coefficients of determination $\left(\mathrm{R}^{2}\right)$ were derived $(\mathrm{r} 2 \mathrm{glmm}$ package in $\mathrm{R}$ using the Nakagawa and Schielzeth approach, Nakagawa and Schielzeth 2013).

\section{Results}

\section{Mass Loss by Forest Type and Tree Species}

Overall, mass loss of fine roots varied among forest types (Figure S3). Across sites, mean mass loss of site-specific litter decreased in the following order: Mediterranean thermophilous forest (Italy, 16士 $0.7 \%$ ) $>$ hemiboreal forest (Poland, $13 \pm 0.9 \%$ ) > boreal forest (Finland, $12 \pm 1.7 \%$ ) $>$ mountainous mixed beech forest (Romania, $11 \pm 0.8 \%$ ).

Fine-root litter mass loss further varied among site-specific litter species (Figure 2, left panel). Fine roots of Pinus sylvestris in boreal forests showed the slowest mass loss during the one-year incubation period, losing on average $8 \pm 0.8 \%$ of the initial litter mass, while roots of Quercus petraea in Mediterranean thermophilous forests decomposed the fastest, with $22 \pm 1.3 \%$ of the initial mass lost.

Fine-root mass loss of the two standard species also differed significantly. Across all sites, roots of Carpinus betulus showed significantly faster mass loss ( $14 \pm 0.6 \%$ of initial mass) than those of Pinus sylvestris ( $10 \pm 0.4 \%$ of initial mass) (Figure S4). In addition, root mass loss of both standard litter species varied among sites, and differences between sites were considerably higher in C. betulus (Figures 2, S4).

\section{Diversity Effects}

Across all four sites, tree species mixing effects on fineroot litter mass loss were significantly positive $(P=$ $0.01)$; that is, single-species litter in monospecific stands decomposed slower than mixed-species litter in mixed-species stands (Figure 3). Within mixed stands, mass loss of single-species litter did not significantly differ from mixed-species litter, indi- cating no litter mixing effects (Figure 3). Moreover, tree diversity tended to accelerate mass loss through a change in the decomposition environment, as shown by higher decomposition of sitespecific single-species fine-root litter in mixed stands compared to single-species fine-root litter in monospecific stands (microenvironmental diversity effect, $P=0.03$ ), though mass loss of standard species litter did not significantly differ between mixed and monospecific stands.

Diversity effects differed among sites (Figure 3). Tree species mixing effects tended to be positive in mountainous beech forest $(P=0.09)$, while they were significantly positive in hemiboreal forests $(P$ $=0.03$, Figure 3 ) and additive in thermophilous deciduous and boreal forests. In contrast, litter mixing effects did not occur at any of the four sites (Figure 3). Moreover, positive microenvironmental diversity effects on site-specific root litter were significant in mountainous beech forests $(P<0.01)$ as well as in hemiboreal forests $(P=0.03)$. We also observed a tendency for a positive microenvironmental diversity effect on the two standard litter species $(P=0.08)$, despite no such effect across all sites.

\section{Functional Trait Dissimilarity}

Neither the multidimensional trait divergence based on eight initial root traits, nor the divergence in single root traits, except for initial root $\mathrm{N}$, predicted tree species mixing effects of root litter mass loss across the four sites (Figure S5, Tables S38S4). The dissimilarity in initial root $\mathrm{N}$ concentrations had a negative but weak $\left(P=0.05, \mathrm{mR}^{2}=0.14\right)$ effect on tree species mixing effects (Figure $\mathrm{S} 5 \mathrm{~b}$ ).

\section{Relative Importance of Diversity, Initial Litter Quality, and Site Conditions}

\section{Initial Litter Quality (Site-Specific Litter)}

The overall positive tree diversity effect across sites accounted only for $2 \%$ of the data variation $(P=$ 0.047). LMM analysis showed that, besides an effect of tree species diversity, mass loss of sitespecific fine-root litter was mainly determined by initial root litter chemistry, that is, initial root $\mathrm{C} / \mathrm{N}$, $\mathrm{Mg}$, and $\mathrm{P}$ concentrations (Table 1). Initial root $\mathrm{Mg}$ concentrations had the strongest (negative) effect on site-specific litter mass loss $\left(P<0.001, \mathrm{mR}^{2}=\right.$ 0.14 ), followed by initial root $P$ concentrations, which had a positive influence on mass loss across sites $\left(P<0.001, \mathrm{mR}^{2}=0.11\right)$. Moreover, root $\mathrm{C} / \mathrm{N}$ had a significant positive but weak effect on mass loss $\left(P<0.01, \mathrm{mR}^{2}=0.06\right)$. 

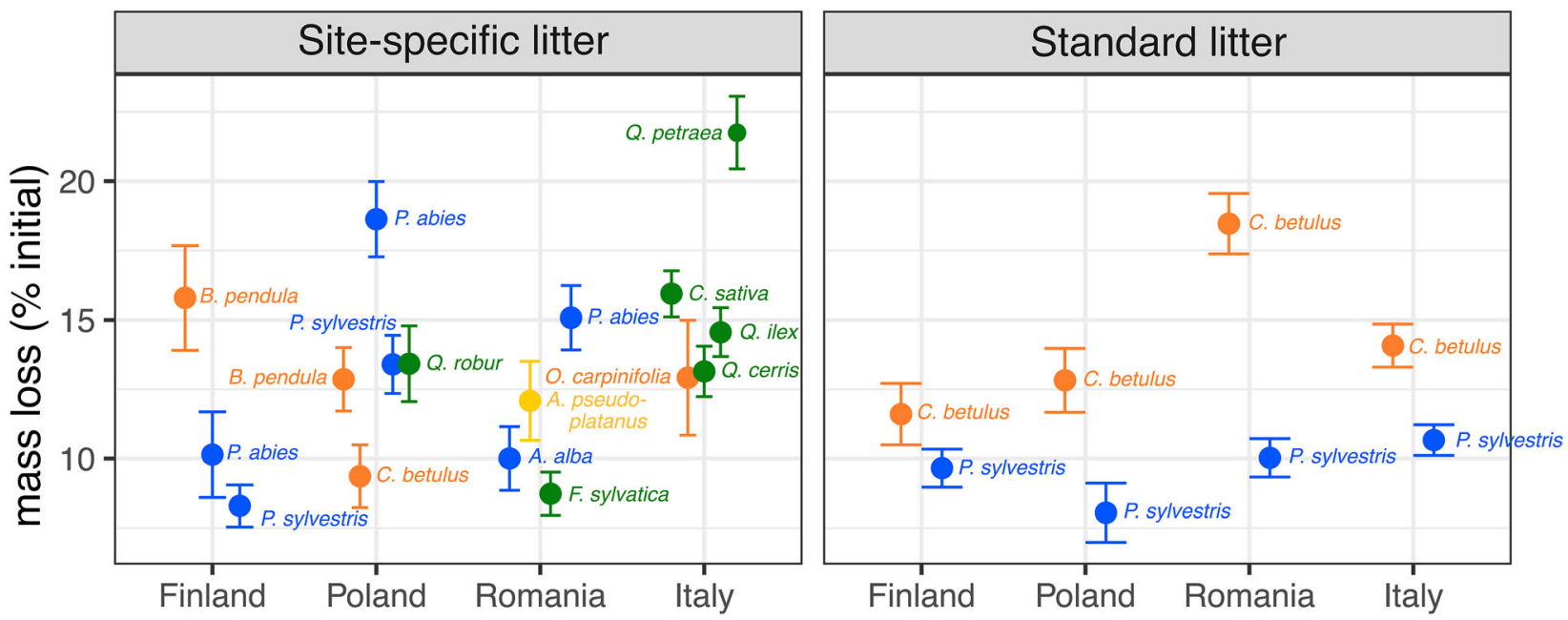

Figure 2. Mean mass loss ( \pm SE) of the site-specific (left panel) and standard litter species (right panel) by site. Mean values were derived from mass loss data of single-species litter bags. Data points of standard litter species only include data from plots where these species were not represented in the tree triplets. Colors indicate common phylogenetic background (family): Fagaceae (green), Betulaceae (orange), Pinaceae (blue), Sapindaceae (yellow).

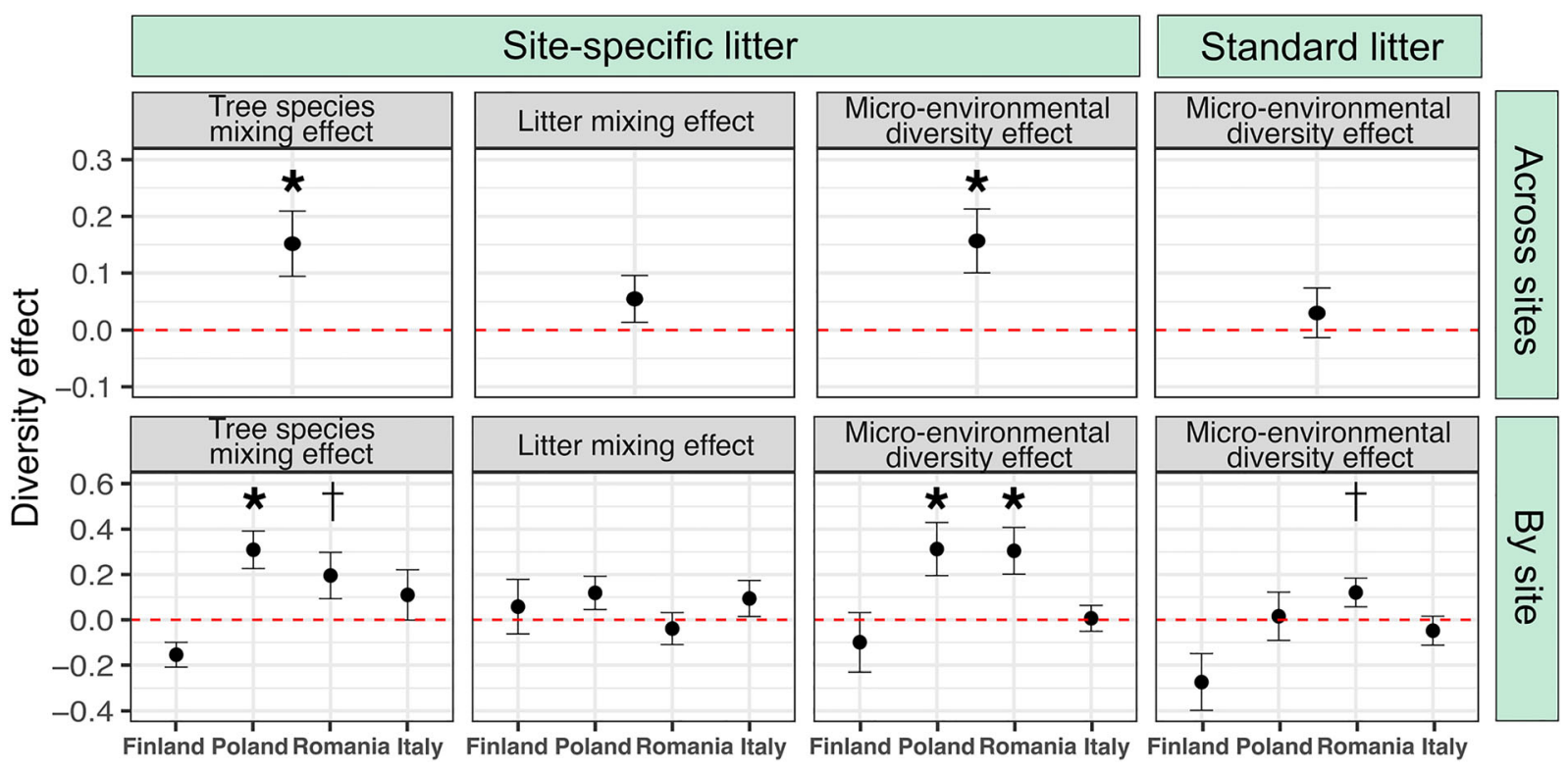

Figure 3. Mean diversity effects $( \pm S E$ ) across sites (upper panels) and by site (lower panels), respectively, for tree species mixing (single-species litter in monospecific stands vs. mixed-species litter in mixed stands), litter mixing (single-species litter in mixed stands vs. mixed-species litter in mixed stands), microenvironmental diversity effects (single-species litter in monospecific stands vs. single-species litter in mixed stands) for site-specific (left) and standard litter species (right). Asterisks indicate significant difference from zero $(\dagger P<0.1, * P<0.05)$.

\section{Environmental Influences (Standard Litter)}

The synthesis model showed that MAP and the species identity of root litter were the most important predictors of mass loss across the four sites $\left(P=0.01, \mathrm{mR}^{2}=0.08\right.$ and $P<0.001, \mathrm{mR}^{2}=$ 0.07 , respectively) (Table 1). Topsoil properties (soil PC1) significantly affected mass loss of standard species' litter $(P<0.01)$, yet only explained $4 \%$ of the variation, whereas forest floor properties (forest floor PC2) had only a marginal effect $\left(P=0.04, \mathrm{mR}^{2}\right.$ $=0.01)$. Significant interactions between species and MAP and MAT, respectively, further indicate that mass loss of the two species was differently affected by macroenvironmental conditions. In the most parsimonious model, tree species diversity 
Table 1. Results of Syntheses Models for Site-specific and Standard Root Litter

\begin{tabular}{|c|c|c|c|c|c|c|}
\hline Fixed effects & Estimate & $t$-value & $P$ & $R^{2}$ & Upper cl & Lower cl \\
\hline & \multicolumn{6}{|c|}{ Mass loss (\% initial) of site-specific litter } \\
\hline Tree diversity & 0.28 & 2.04 & $<0.05$ & 0.02 & 0.06 & 0.00 \\
\hline Root $\mathrm{C} / \mathrm{N}$ & 0.54 & 3.47 & $<0.01$ & 0.06 & 0.13 & 0.02 \\
\hline Root Mg & -0.56 & -3.88 & $<0.001$ & 0.14 & 0.22 & 0.07 \\
\hline Root P & 0.57 & 4.26 & $<0.001$ & 0.11 & 0.17 & 0.03 \\
\hline $\mathrm{mR}^{2}$ & \multirow{2}{*}{\multicolumn{3}{|c|}{0.18}} & 0.18 & 0.28 & 0.11 \\
\hline \multirow[t]{2}{*}{$\mathrm{cR}^{2}$} & 0.55 & & & & & \\
\hline & \multicolumn{6}{|c|}{ Mass loss (\% initial) of standard litter } \\
\hline \multicolumn{7}{|l|}{ Tree diversity } \\
\hline Species & -0.48 & -6.73 & $<0.001$ & 0.07 & 0.11 & 0.03 \\
\hline Soil PC1 & -0.27 & -3.11 & $<0.01$ & 0.04 & 0.08 & 0.01 \\
\hline \multicolumn{7}{|l|}{ Soil PC2 } \\
\hline Forest floor PC2 & -0.11 & -2.13 & 0.04 & 0.01 & 0.04 & 0.00 \\
\hline MAT & -0.19 & -1.20 & 0.29 & 0.01 & 0.40 & 0.0 \\
\hline MAP & 0.65 & 3.64 & 0.01 & 0.08 & 0.13 & 0.04 \\
\hline \multicolumn{7}{|c|}{ Species * Forest floor PC2 } \\
\hline \multicolumn{7}{|c|}{ Species * Soil PC1 } \\
\hline \multicolumn{7}{|c|}{ Species * Soil PC2 } \\
\hline Species * MAT & 0.37 & 3.93 & $<0.001$ & 0.02 & 0.06 & 0.01 \\
\hline Species * MAP & -0.56 & -6.03 & $<0.001$ & 0.06 & 0.10 & 0.02 \\
\hline $\mathrm{mR}^{2}$ & \multicolumn{3}{|c|}{0.16} & 0.16 & 0.22 & 0.11 \\
\hline $\mathrm{cR}^{2}$ & \multicolumn{3}{|c|}{0.31} & & & \\
\hline
\end{tabular}

Bold letters indicate significant effects

The predictor variables included in these models were selected based on a series of previous models and applying model selection and averaging (Tables S5-S8). The response variables were transformed to comply with model assumptions (orderNorm for site-specific litter mass loss and square root for standard litter mass loss). Marginal and conditional coefficients of determinations $\left(m R^{2}\right.$ and $\left.c R^{2}\right)$ indicate the variation explained by the fixed effects $\left(m R^{2}\right)$ and fixed and random effects combined (c $\left.R^{2}\right)$, respectively. Coefficients of determinations $\left(R^{2}\right)$ for each fixed effect, including upper and lower confidence limits (Cl), were derived using the Nakagawa and Schilzeth approach. Red and green shaded areas indicate negative and positive slopes, respectively. Gray-shaded cells indicate variables that were dropped after model selection and averaging. MAT Mean annual temperature, MAP mean annual precipitation, PC principal component.

was dropped as a predictor variable for standard species' mass loss. Similarly, microclimate variables did not affect standard litter mass loss across sites and were not included in the synthesis model (Table S7).

\section{Discussion}

In this study, we tested the decomposition of absorptive fine roots of site-specific and standard tree species in response to species mixing across a broad environmental gradient. Across all sites, we observed positive but rather weak overall tree species mixing effects on fine-root litter mass loss. Indirect effects through tree diversity at litter incubation sites contributed more to this acceleration of litter mass loss than direct litter species mixing effects. The dissimilarity in initial root traits contributed little to explain diversity effects. The differences among forest types and between litters (site-specific versus standard litter) indicate inter- actions between regional-scale conditions and litter species influencing diversity effects. Overall, initial root substrate quality and site effects played a stronger role in root litter mass loss than tree diversity.

\section{Diversity Effects on Fine-Root Litter Mass Loss Across Sites}

In accordance with our first hypothesis, tree diversity effects on fine-root litter mass loss were overall nonadditive and positive across the four forest types and 21 litter mixture compositions (Figure 3). These results corroborate findings of two recent meta-analyses reporting generally positive diversity effects for leaf litter decomposition across biomes (Kou and others 2020; Liu and others 2020).

Our study design allowed us to separate tree species mixing effects into those attributable to litter species mixing (direct species interactions, Hättenschwiler 2005) and those related to 
microenvironmental changes in mixed-species compared to monospecific plots (indirect effects, Hector and others 2000). A positive microenvironmental diversity effect and the lack of a litter mixing effect are not in line with our second and third hypothesis and indicate that the tree species mixing effects were mainly attributable to indirect drivers (Figure 3).

\section{Indirect Effects}

Several indirect effects may explain the accelerated mass loss of root litter in mixed compared to monospecific neighborhoods. Changes in microenvironmental conditions, such as modifications of the tree canopy in mixtures compared to monospecific stands, may be drivers of these nonadditive effects. This was suggested by another study across the FunDivEUROPE plot network reporting a tendency for accelerated cellulose paper mass loss rates in response to tree species richness (Joly and others 2017). Such indirect effects may also entail changes in edaphic conditions in mixed compared to monospecific stands (Vesterdal and others 2013; Dawud and others 2016), which could be associated with changes in soil fauna (Hättenschwiler and Gasser 2005) and microbial community composition (Scheibe and others 2015). Higher $\mathrm{P}$ concentrations and lower $\mathrm{C} / \mathrm{N}$ in forest floor in mixed than in monospecific plots across our sites (Gillespie and others 2021) could indicate more favorable conditions for decomposers (Hobbie and Vitousek 2000).

During the incubation year and its vegetation period, soil temperature tended to be lower in mixtures than in monospecific stands (Table S9). During the severe summer drought of 2018, the lower soil temperatures may have created more favorable conditions for decomposer organisms. Linked to this could be lower fluctuations in temperature and soil moisture under a denser canopy in mixed stands, as speculated by Joly and others (2017) who reported positive effects of leaf area index on cellulose decomposition across European forests. Higher canopy density was indeed observed with increasing species richness across the same plot network (Jucker and others 2015). Changes in soil microbial community structure, for example, higher abundance or diversity of decomposing microbes in response to higher tree diversity, could have also accelerated decomposition rates (Chapman and others 2013). The higher mycorrhizal fungi diversity reported for mixed compared to monospecific stands across our sites (Wambsganss and others 2021b) may indeed substantiate this speculation.

Interestingly, overall, microenvironmental diversity effects were only significant for sitespecific but not standard root litter species (Figure 3), implying that these effects depend on context and litter type. For instance, this observation could suggest that the microbial decomposer communities present may have the capacity to decompose certain (recalcitrant) root litter compounds present in the site-specific litter species but not in the standard litter species, following the home-field advantage hypothesis (Ayres and others 2009).

\section{Direct Effects}

The lack of a litter mixing effect suggests that under the same canopy, mass loss of mixed-species litter can be predicted from the component single-species mass loss. Such additive effects under homogeneous conditions (that is, canopy) have also been reported for root litter in studies in subtropical ( $\mathrm{Li}$ and others 2018) and tropical forests (GuerreroRamírez and others 2016). However, these bulk additive effects cannot be interpreted as the absence of interaction among the different species. Since we did not determine mass loss of the individual species in the mixed-litter bags, we cannot exclude the possibility that both synergistic and antagonistic interactions among litter species occurred simultaneously, resulting in an overall neutral effect (Hättenschwiler and others 2005). To account for such divergent patterns, future studies should attempt to separate component species from mixed-litter bags, possibly using indirect methods of species identification in the fragmented and partly decomposed material (Gruselle and Bauhus 2010).

\section{Role of Root Trait Dissimilarity}

The dissimilarity in initial root traits (FDis) did not predict tree species mixing effects on fine-root litter mass loss across sites (Figure S5a), contradicting our fourth hypothesis but corroborating a range of other studies on leaf litter mixing (Chapman and others 2013; Tardif and Shipley 2015; Lin and Zeng 2018). Here, these findings may be linked to the weak diversity effects and could point to the omission of key chemical traits, including lignin or condensed tannins (Sun and others 2018). Another explanation may entail the absence of soil macrofauna due to the litter-bag approach, which can determine the magnitude of positive litter trait dissimilarity effects (Barantal and others 2014), 
likely owing to complementary resource use by detritivores (Vos and others 2013). A possibly better soil nutrient availability in mixtures could also reduce the importance of (microbial) nutrient transfer among litter species, as a result of a sufficient supply of nutrients to microbes (Frainer and others 2015).

Interestingly, litter mixtures that varied most in initial $\mathrm{N}$ concentrations showed the lowest mass loss compared to observations from single-species litter (Figure S5b). Such negative effects of litter functional diversity, including several chemical traits, were also observed for leaf litter decomposition (Grossman and others 2020), including N (Kou and others 2020). Though the negative effect detected here was rather weak, it points to a complex interplay of litter interaction effects with environmental conditions (Lummer and others 2012).

\section{Mean Mass Loss}

In general, mass loss of both site-specific and standard litter species varied among sites and was extremely low (Figures 2, S3) in face of the decomposition rates reported by related global meta-analyses for roots $\leq 2 \mathrm{~mm}$ in diameter $(0.69 \pm$ $0.17 \mathrm{y}^{-1}$, Silver and Miya 2001; $0.75 \pm 0.04 \mathrm{y}^{-1}$, Zhang and Wang 2015). This is especially true given that decomposition rates in early-stage decomposition phases may even be higher than those during later stages (Sun and others 2018). Nevertheless, findings by others focusing on lowerorder roots ( $k$ of $0.11 \pm 0.01 \mathrm{y}^{-1}$ in temperate climates, Sun and others (2018) or 0.002-0.085 $\mathrm{y}^{-1}$, in temperate and subtropical tree roots, Xiong and others (2013)) also reported comparably low decomposition rates.

Yet, in view of the relatively short life spans (much less than one year) and high turnover rates of the most distal root orders (McCormack and others 2012), this extremely low mass loss is presumably highly underestimated. It suggests unrealistically high fine-root necromass values in soils exceeding fine-root biomass values by several orders of magnitudes. This is unrealistic, as the average fine-root necromass across European forests was estimated to be only slightly higher than the fine-root biomass ( 379 vs. $332 \mathrm{~g} \mathrm{~m}^{-2}$ year $^{-1}$, for the bulk of roots $\leq 2 \mathrm{~mm}$ in diameter) (Neumann and others 2021).

The underestimation of mass loss may partially be attributable to the litter-bag technique and the artificial decomposition environment it creates (Dornbush and others 2002; Beidler and Pritchard 2017). The small mesh size used here excludes meso- and macrofauna (Song and others 2020), essentially affecting decomposition of root litter (Bradford and others 2002). Potential intraspecific changes in root morphological and chemical characteristics between mixed- and monospecific stands as well as among sites (Wambsganss and others $202 \mathrm{lb}$ ), which could have altered the quality of root litter and possibly accelerated decomposition rates, were not taken into account in this study, as the site-specific litter material did not actually originate from the respective sites. In addition, the severe summer drought in 2018 across Europe could have further hampered microbial decomposition at our sites. Consequently, the generally very low mass loss measured here could be partially responsible for the lack of strong diversity effects and overall relatively low variation explained by the predictor variables.

\section{Differences Among Forest Types}

The relatively weak tree species mixing effects across sites and thereby among forest types (Figure 3) further corroborate findings of context dependency of tree diversity effects for aboveground litter decomposition (Kou and others 2020; Liu and others 2020; Zhou and others 2020). Yet, this stands in contrast to reports of no changes in the magnitude of diversity effects on root decomposition under variable environmental conditions (for example, soil fertility) (Guerrero-Ramírez and others 2016).

In hemiboreal forests (Poland), where the tree species mixing effects were strongest, a previous study reported increasing forest floor $\mathrm{pH}$ values with increasing tree species diversity (Dawud and others 2016), thereby likely improving conditions for microbial decomposition. The weak (and not significant) negative tree species mixing effects on fine-root decomposition in boreal forests (Finland) support findings from a meta-analysis on leaf litter (Liu and others 2020) and may be explained by the generally lower decomposer activity in these climates. A slightly lower soil temperature in mixtures compared to monospecific stands during the vegetation period 2018 (Table S9) could have had a particularly large (negative) effect on the activity of decomposing microorganisms (Pietikäinen and others 2005; Conant and others 2011) in boreal forests, as soil and air temperatures in these forests are generally much lower during the year than in the other forest ecosystems studied here. By contrast, in thermophilous deciduous forests (Italy), a slightly lower annual soil and air temperature in mixed than monospecific stands could have had a 
positive effect on decomposers, as high temperatures coupled with low soil moisture during summer months could hamper decomposition at these sites.

Besides contrasts in environmental conditions among sites, the different litter species' pools incubated at the four sites (and thereby different interactions of the different litter types with environmental conditions), likely also influenced the occurrence and magnitude of the diversity effects.

\section{Relative Importance of Influences on Mass Loss}

The analyses of site-specific and standard root litter showed that both initial litter quality and site conditions determined fine-root litter mass loss more strongly than tree diversity. The variability of diversity effects across sites is largely responsible for this overall low influence of tree diversity on decomposition, yet these findings are consistent with other studies (Schindler and Gessner 2009; Frainer and others 2015; Zhou and others 2020). The positive effect of initial root $\mathrm{P}$ on mass loss has been pointed out in a global meta-analysis (See and others 2019), whereas the positive relationship of root $\mathrm{C} / \mathrm{N}$ with mass loss does not seem straightforward. While initial $\mathrm{C} / \mathrm{N}$ may be a good predictor of leaf litter decomposition rates, it may not take the same role for the decomposition of first-order roots (Sun and others 2018) as, for example, incubation of freshly killed rather than senesced roots elude the $\mathrm{C}$ and nutrient resorption processes (Freschet and others 2020). A high EcM colonization, which was the case for many of the incubated roots here (Table S2), can slow down litter mass loss, despite a relatively low $\mathrm{C} / \mathrm{N}$ ratio (Langley and others 2006), owing to the presence of N-rich chitin from the fungus (Langley and others 2006). The negative effect of initial root $\mathrm{Mg}$ concentration on fine-root litter mass loss contrasts most other studies (Beidler and Pritchard 2017; Chen and others 2017b; Sun and others 2018), yet has been observed before (Goebel and others 2011; Sun and others 2013; Jiang and others 2020). The chemical composition of EcM could also play a role here, as speculated by Jiang and others (2020).

Yet, the large number of root traits investigated here did not contribute much to predict mass loss. Altogether, the relatively low variance explained by these root traits may indicate the omission of key traits in our study influencing the decomposition process of fine roots. For the most distal root orders, these may include lignins, condensed tan- nins, and non-structural carbohydrates (Sun and others 2018).

MAP and species' identity were the most important predictors among the variables included in our models of standard root litter mass loss across sites (Table 1). In particular for the finest root orders, initial litter quality may be the primary determinant of fine-root litter mass loss, and thereby more important than environmental conditions, including macroclimate (Silver and Miya 2001; Zhang and Wang 2015). In contrast, topsoil and forest floor properties only explained a marginal proportion of the variation in root litter mass loss (Table 1). This contradicts another study of standard root litter in forests (Solly and others 2014), but is in line with findings from grasslands, where soil abiotic conditions did also not affect root litter decomposition (Chen and others 2017b). Still, we acknowledge that other environmental variables, such as edaphic factors and decomposer community composition, that were not included in the models but that may have been highly correlated with macroclimatic variables, could have played an important role in driving standard root litter mass loss rates. Furthermore, the significant interactions of litter identity with MAP and MAP (Table 1), respectively, point to the complex interplay of macroenvironmental conditions, affecting decomposer organisms, with initial litter quality. The study of such interactions is likely key to interpret the context dependency of plant diversity effects on decomposition over large spatial scales.

\section{ConClusions}

Overall, our results extend the findings of other studies of mixture effects on leaf litter decomposition. Also in fine roots, the environmental context and initial litter chemistry can be more important predictors of litter decomposition than species mixing. Nonetheless, litter diversity effects differed strongly across forest types and in interaction with macroclimate variables, suggesting that incorporating diversity effects and their context dependency in ecological models of carbon and nutrient cycling is likely to be crucial to avoid biased outcomes. Future studies should, therefore, investigate further the interplay of forest characteristics and the decomposer community in mixed-species forests. In addition, expanding the list of functional fine-root traits to include relevant properties such as lignins and condensed tannins could also improve our mechanistic understanding of diversity effects. 


\section{ACKNOWLEDGEMENTS}

This study was funded by the German Research Foundation (Grant numbers: BA 2821/16-1 and SCHE 695/10-1). This research was part of the SoilForEUROPE project funded through the 20152016 BiodivERsA COFUND call for research proposals, with the national funders Agence Nationale de la Recherche (ANR, France), Belgian Science Policy Office (BELSPO, Belgium), Deutsche Forschungsgemeinschaft (DFG, Germany), Research Foundation Flanders (FWO, Belgium), and the Swedish Research Council (FORMAS, Sweden). FB was supported by the Margarete-vonWrangell Fellowship of the Ministry of Science, Research and the Arts Baden-Württemberg and European Social Fund. We thank the site managers Leena Finér, Finnish Forest Research Institute (LUKE), Bogdan Jaroszewicz, University of Warsaw, Poland, Olivier Bouriaud, Forest Research, and Management Institute (ICAS), Romania, Filippo Bussotti and Federico Selvi, University of Florence, Italy, as well as the SoilForEUROPE consortium for their assistance with the soil sampling campaign. We further thank Radim Matula from the University of Life Sciences, Prague, Czech Republic, and Roman Plichta from the Mendel University, Brno, Czech Republic, for the microclimate data. Bart Muys and Karen Vancampenhout at KU Leuven University provided soil texture data. We thank Lauren Gillespie and her team for conducting forest floor analysis at the experimental platform PACE at CEFE Montpellier, France. We are grateful for field work support by Timo Domisch, Irek Smerczyński, and Iulian Dănilă and thank Nicole Shanahan, Lisa Zeigner, Renate Nitschke, and Germar Csapek for their assistance in the laboratory.

\section{FUNDING}

Open Access funding enabled and organized by Projekt DEAL.

Open Access This article is licensed under a Creative Commons Attribution 4.0 International License, which permits use, sharing, adaptation, distribution and reproduction in any medium or format, as long as you give appropriate credit to the original author(s) and the source, provide a link to the Creative Commons licence, and indicate if changes were made. The images or other third party material in this article are included in the article's Creative Commons licence, unless indicated otherwise in a credit line to the material. If material is not included in the article's Creative Commons licence and your intended use is not permitted by statutory regulation or exceeds the permitted use, you will need to obtain permission directly from the copyright holder. To view a copy of this licence, visit http://creativecommons.org/ licenses/by/4.0/.

\section{DATA AVAILABILITY}

The datasets used for this study will be archived on a data portal associated with the FunDivEUROPE and SoilForEUROPE projects (https://data.botanik. uni-halle.de/fundiveurope) and freely accessible to the public.

\section{REFERENCES}

Adamczyk B, Sietiö OM, Biasi C, Heinonsalo J. 2019. Interaction between tannins and fungal necromass stabilizes fungal residues in boreal forest soils. New Phytol 223:16-21.

Angst G, Mueller KE, Nierop KGJ, Simpson MJ. 2021. Plant- or microbial-derived? A review on the molecular composition of stabilized soil organic matter. Soil Biol Biochem 156:108189. https://doi.org/10.1016/j.soilbio.2021.108189.

Ayres E, Steltzer H, Simmons BL, Simpson RT, Steinweg JM, Wallenstein MD, Mellor N, Parton WJ, Moore JC, Wall DH. 2009. Home-field advantage accelerates leaf litter decomposition in forests. Soil Biol Biochem 41:606-610. https://doi. org/10.1016/j.soilbio.2008.12.022.

Baeten L, Verheyen K, Wirth C, Bruelheide H, Bussotti F, Finér L, Jaroszewicz B, Selvi F, Valladares F, Allan E, Ampoorter E, Auge $\mathrm{H}$, Avăcăriei D, Barbaro L, Bărnoaiea I, Bastias CC, Bauhus J, Beinhoff C, Benavides R, Benneter A, Berger S, Berthold F, Boberg J, Bonal D, Brüggemann W, Carnol M, Castagneyrol B, Charbonnier Y, Chećko E, Coomes D, Coppi A, Dalmaris E, Dǎnilă G, Dawud SM, de Vries W, De Wandeler H, Deconchat M, Domisch T, Duduman G, Fischer M, Fotelli M, Gessler A, Gimeno TE, Granier A, Grossiord C, Guyot V, Hantsch L, Hättenschwiler S, Hector A, Hermy M, Holland V, Jactel H, Joly FX, Jucker T, Kolb S, Koricheva J, Lexer MJ, Liebergesell M, Milligan H, Müller S, Muys B, Nguyen D, Nichiforel L, Pollastrini M, Proulx R, Rabasa S, Radoglou K, Ratcliffe S, Raulund-Rasmussen K, Seiferling I, Stenlid J, Vesterdal L, von Wilpert K, Zavala MA, Zielinski D, SchererLorenzen M. 2013. A novel comparative research platform designed to determine the functional significance of tree species diversity in European forests. Perspect Plant Ecol Evol Syst 15:281-291.

Barantal S, Roy J, Fromin N, Schimann H, Hättenschwiler S. 2011. Long-term presence of tree species but not chemical diversity affect litter mixture effects on decomposition in a neotropical rainforest. Oecologia 167:241-252.

Barantal S, Schimann H, Fromin N. 2014. C, N and P fertilization in an Amazonian rainforest supports stoichiometric dissimilarity as a driver of litter diversity effects on decomposition. Proc R Soc B 281.

Bartoń K. 2019. MuMln: multi-model inference.

Bates D, Mächler M, Bolker B, Walker S. 2015. Fitting linear mixed-effects models using lme4. J Stat Softw 67:1-48.

Bauhus J, Forrester DI, Pretzsch H. 2017. Mixed-species forests: The development of a forest management paradigm. In: 
Pretzsch H, Forrester DI, Bauhus J, editors. Mixed-species forests. Springer. pp 1-26.

Beidler KV, Pritchard SG. 2017. Maintaining connectivity: understanding the role of root order and mycelial networks in fine root decomposition of woody plants. Plant Soil 420:1936.

Berg B. 1984. Decomposition of root litter and some factors regulating the process: long-term root litter decomposition in a scots pine forest. Soil Biol Biochem 16:609-617.

Berg B. 2014. Decomposition patterns for foliar litter-a theory for influencing factors. Soil Biol Biochem 78:222-232.

Beyer F, Hertel D, Jung K, Fender AC, Leuschner C. 2013. Competition effects on fine root survival of Fagus sylvatica and Fraxinus excelsior. For Ecol Manag 302:14-22. https:// doi.org/10.1016/j.foreco.2013.03.020.

Bradford MA, Tordoff GM, Eggers T, Jones TH, Newington JE. 2002. Microbiota, fauna, and mesh size interactions in litter decomposition. Oikos 99:317-323.

Brant AN, Chen HYH. 2015. Patterns and mechanisms of nutrient resorption in plants. CRC Crit Rev Plant Sci 34:471486. https://doi.org/10.1080/07352689.2015.1078611.

Burnham KP, Anderson DR. 2002. Model selection and multimodel inference: a practical information-theoretic approach, 2nd edn. New York: Springer-Verlag.

Chapman SK, Newman GS, Hart SC, Schweitzer JA, Koch GW. 2013. Leaf litter mixtures alter microbial community development: mechanisms for non-additive effects in litter decomposition. PLoS One 8.

Chen H, Mommer L, Van Ruijven J, De Kroon H, Fischer C, Gessler A, Hildebrandt A, Scherer-Lorenzen M. 2017a. Plant species richness negatively affects root decomposition in grasslands. J Ecol 105:209-218.

Chen H, Oram NJ, Barry KE, Mommer L, Van Ruijven J, Scheu S, Oelmann Y, Wagg C, Wilcke W, Wirth C. 2017b. Root chemistry and soil fauna, but not soil abiotic conditions explain the effects of plant diversity on root decomposition. Oecologia 185:499-511.

Conant RT, Ryan MG, Ågren GI, Birge HE, Davidson EA, Eliasson PE, Evans SE, Frey SD, Giardina CP, Hopkins FM, Hyvönen R, Kirschbaum MUF, Lavallee JM, Leifeld J, Parton WJ, Megan Steinweg J, Wallenstein MD, Martin Wetterstedt JÅ, Bradford MA. 2011. Temperature and soil organic matter decomposition rates - synthesis of current knowledge and a way forward. Glob Change Biol 17:3392-3404.

Cotrufo MF, Wallenstein MD, Boot CM, Denef K, Paul E. 2013. The Microbial Efficiency-Matrix Stabilization (MEMS) framework integrates plant litter decomposition with soil organic matter stabilization: Do labile plant inputs form stable soil organic matter? Glob Change Biol 19:988-995.

Dawud SM, Raulund-Rasmussen K, Domisch T, Finér L, Jaroszewicz B, Vesterdal L. 2016. Is tree species diversity or species identity the more important driver of soil carbon stocks, C/N ratio, and pH? Ecosystems 19:645-660.

Dawud SM, Raulund-Rasmussen K, Ratcliffe S, Domisch T, Finér L, Joly FX, Hättenschwiler S, Vesterdal L. 2017. Tree species functional group is a more important driver of soil properties than tree species diversity across major European forest types. Funct Ecol 31:1153-1162.

Dornbush ME, Isenhart TM, Raich JW. 2002. Quantifying fineroot decomposition: an alternative to buried litterbags. Ecology 83:2985-2990.
Fox J, Weisberg S. 2011. An $\{R\}$ companion to applied regression, Second Edition. http://socserv.socsci.mcmaster.ca/jfox/ Books/Companion

Frainer A, Moretti MS, Xu W, Gessner MO. 2015. No evidence for leaf-trait dissimilarity effects on litter decomposition, fungal decomposers, and nutrient dynamics. Ecology 96:550561.

Freschet GT, Cornwell WK, Wardle DA, Elumeeva TG, Liu W, Jackson BG, Onipchenko VG, Soudzilovskaia NA, Tao J, Cornelissen JHC. 2013. Linking litter decomposition of aboveand below-ground organs to plant-soil feedbacks worldwide. J Ecol 101:943-952.

Freschet GT, Pagès L, Iversen C, Comas L, Rewald B, Roumet C, Klimešová $\mathrm{J}$, Zadworny $\mathrm{M}$, Poorter $\mathrm{H}$, Postma $\mathrm{J}$, Adams $\mathrm{T}$, Bagniewska-Zadworna A, Bengough A, Blancaflor E, Brunner I, Cornelissen J, Garnier E, Gessler A, Hobbie SE, Meier IC, Mommer L, Picon-Cochard C, Rose L, Ryser P, SchererLorenzen M, Soudzilovskaia NA, Stokes A, Sun T, ValverdeBarrantes OJ, Weemstra M, Weigelt A, Wurzburger N, York LM, Batterman S, Gomes de Moraes M, Janecek S, Lambers H, Salmon V, Tharayil N, McCormack M. 2020. A starting guide to root ecology: strengthening ecological concepts and standardizing root classification, sampling, processing and trait measurements. hal hal-029188.

Gartner TB, Cardon ZG. 2004. Decomposition dynamics in mixed-species leaf litter. OIKOS 104:230-246.

Gessner MO, Swan CM, Dang CK, McKie BG, Bardgett RD, Wall DH, Hättenschwiler S. 2010. Diversity meets decomposition. Trends Ecol Evol 25:372-380. https://doi.org/10.1016/j.tree. 2010.01.010

Gillespie LM, Hättenschwiler S, Milcu A, Wambsganss J, Shihan A, Fromin N. 2021. Tree species mixing affects soil microbial functioning indirectly via root and litter traits and soil parameters in European forests. Funct Ecol:1-15.

Goebel M, Hobbie S, Bulaj B, Zadworny M, Archibald D, Oleksyn J, Reich P, Eissenstat D. 2011. Decomposition of the finest root branching orders: Linking carbon and nutrient dynamics belowground to fine root function and structure. Ecol Monogr 81:89-102. https://doi.org/10.1890/09-2390.1.

Gordon WS, Jackson RB. 2000. Nutrient concentrations in fine roots. Ecology 81:275-280.

Grossman JJ, Cavender-Bares J, Hobbie SE. 2020. Functional diversity of leaf litter mixtures slows decomposition of labile but not recalcitrant carbon over two years. Ecol Monogr 90:119.

Gruselle MC, Bauhus J. 2010. Assessment of the species composition of forest floor horizons in mixed spruce-beech stands by Near Infrared Reflectance Spectroscopy (NIRS). Soil Biol Biochem 42:1347-1354.

Guerrero-Ramírez NR, Craven D, Messier C, Potvin C, Turner BL, Handa IT. 2016. Root quality and decomposition environment, but not tree species richness, drive root decomposition in tropical forests. Plant Soil 404:125-139. https://doi. org/10.1007/s11104-016-2828-y.

Hättenschwiler S. 2005. Effects of tree species diversity on litter quality and quantity. In: Scherer-Lorenzen M, Körner C, Schulze E-D, Eds. Forest diversity and function: temperate and boreal systems, . Berlin Heidelberg: Springer. pp 149-164.

Hättenschwiler S, Gasser P. 2005. Soil animals alter plant litter diversity effects on decomposition. Proc Natl Acad Sci USA 102:1519-1524. 
Hättenschwiler S, Tiunov AV, Scheu S. 2005. Biodiversity and litter decomposition in terrestrial ecosystems. Annu Rev Ecol Evol Syst 36:191-218.

Hättenschwiler S, Vitousek PM. 2000. The role of polyphenols in terrestrial ecosystem nutrient cycling. Trends Ecol Evol $15: 238-243$

Hector A, Beale AJ, Minns A, Otway SJ, Lawton JH. 2000. Consequences of the reduction of plant diversity for litter decomposition: effects through litter quality and microenvironment. Oikos 90:357-371.

Hobbie SE. 2015. Plant species effects on nutrient cycling: revisiting litter feedbacks. Trends Ecol Evol 30:357-363. https://doi.org/10.1016/j.tree.2015.03.015.

Hobbie SE, Oleksyn J, Eissenstat DM, Reich PB. 2010. Fine root decomposition rates do not mirror those of leaf litter among temperate tree species. Oecologia 162:505-513.

Hobbie SE, Vitousek PM. 2000. Nutrient limitation of decomposition in Hawaiian forests. Ecology 81:1867-1877.

Jackson RB, Mooney HAA, Schulze E-DD. 1997. A global budget for fine root biomass, surface area, and nutrient contents. Proc Natl Acad Sci 94:7362-7366.

Jaeger B. 2017. r2glmm: computes R squared for mixed (multilevel) models. https://cran.r-project.org/package $=$ r2glmm

Jiang L, Kou L, Li S. 2019. Decomposition of leaf mixtures and absorptive-root mixtures synchronously changes with deposition of nitrogen and phosphorus. Soil Biol Biochem 138.

Jiang L, Wang H, Li S, Fu X, Dai X, Yan H, Kou L. 2020. Mycorrhizal and environmental controls over root trait-decomposition linkage of woody trees. New Phytol 229:284-295.

Joly FX, Milcu A, Scherer-Lorenzen M, Jean LK, Bussotti F, Dawud SM, Müller S, Pollastrini M, Raulund-Rasmussen K, Vesterdal L, Hättenschwiler S. 2017. Tree species diversity affects decomposition through modified micro-environmental conditions across European forests. New Phytol 214:12811293.

Jucker T, Bouriaud O, Coomes DA. 2015. Crown plasticity enables trees to optimize canopy packing in mixed-species forests. Funct Ecol 29:1078-1086.

Keiluweit M, Nico P, Harmon ME, Mao J, Pett-Ridge J, Kleber M. 2015. Long-term litter decomposition controlled by manganese redox cycling. Proc Natl Acad Sci 112:E5253-E5260. https://doi.org/10.1073/pnas.1508945112.

Korboulewsky N, Perez G, Chauvat M. 2016. How tree diversity affects soil fauna diversity: a review. Soil Biol Biochem 94:94106. https://doi.org/10.1016/j.soilbio.2015.11.024.

Kou L, Jiang L, Hättenschwiler S, Zhang M, Niu S, Fu X, Dai X, Yan H, Li S, Wang H. 2020. Diversity-decomposition relationships in forests worldwide. Elife 9:1-51.

Laliberté E, Legendre P. 2010. A distance-based framework for measuring functional diversity from multiple traits. Ecology 91:299-305.

Laliberté E, Legendre P, Shipley B. 2014. FD: measuring functional diversity from multiple traits, and other tools for functional ecology.

Langley AJ, Chapman SK, Hungate BA. 2006. Ectomycorrhizal colonization slows root decomposition: the post-mortem fungal legacy. Ecol Lett 9:955-959.

Leuschner C, Ellenberg H. 2017. Ecology of Central European Forests. Springer. https://doi.org/10.1007/978-3-319-43042-3

Li Y, Chen X, Veen CGF, Eisenhauer N, Liang Y, Zhou X, Zhang N, Ma K. 2018. Negative effects of litter richness on root decomposition in the presence of detritivores. Funct Ecol. https://doi.org/10.1111/1365-2435.13057.

Lin G, Zeng DH. 2018. Functional identity rather than functional diversity or species richness controls litter mixture decomposition in a subtropical forest. Plant Soil 428:179-193.

Liu J, Liu X, Song Q, Compson ZG, LeRoy CJ, Luan F, Wang H, Hu Y, Yang Q. 2020. Synergistic effects: a common theme in mixed-species litter decomposition. New Phytol 227:757-765.

Loreau M. 1998. Separating sampling and other effects in biodiversity experiments. Nord Soc Oikos 82:600-602.

Lummer D, Scheu S, Butenschoen O. 2012. Connecting litter quality, microbial community and nitrogen transfer mechanisms in decomposing litter mixtures. Oikos 121:1649-1655.

Makkonen M, Berg MP, Van Logtestijn RSP, Van Hal JR, Aerts R. 2013. Do physical plant litter traits explain non-additivity in litter mixtures? A test of the improved microenvironmental conditions theory. Oikos 122:987-997.

McCormack ML, Adams TS, Smithwick EAH, Eissenstat DM. 2012. Predicting fine root lifespan from plant functional traits in temperate trees. New Phytol 195:823-831. https://doi.org/ 10.1111/j.1469-8137.2012.04198.x.

McCormack ML, Dickie IA, Eissenstat DM, Fahey TJ, Fernandez CW, Guo D, Helmisaari HS, Hobbie EA, Iversen CM, Jackson RB, Leppälammi-Kujansuu J, Norby RJ, Phillips RP, Pregitzer KS, Pritchard SG, Rewald B, Zadworny M. 2015. Redefining fine roots improves understanding of below-ground contributions to terrestrial biosphere processes. New Phytol 207:505-518.

McTiernan KB, Ineson P, Coward PA. 1997. Respiration and nutrient release from tree leaf litter mixtures. Oikos 78:527.

Nakagawa S, Schielzeth H. 2013. A general and simple method for obtaining R2 from generalized linear mixed-effects models. Methods Ecol Evol 4:133-142.

Neumann M, Godbold DL, Hirano Y, Finer L. 2021. Improving models of fine root carbon stocks and fluxes in European forests. J Ecol 108:1-19.

Palmborg C, Scherer-Lorenzen M, Jumpponen A, Carlsson G, Huss-Danell K, Högberg P. 2005. Inorganic soil nitrogen under grassland plant communities of different species composition and diversity. Oikos 110:271-282.

Peterson RA. 2017. bestNormalize: A suite of normalizing transformations. https://github.com/petersonR/bestNormalize

Pietikäinen J, Pettersson M, Bååth E. 2005. Comparison of temperature effects on soil respiration and bacterial and fungal growth rates. FEMS Microbiol Ecol 52:49-58.

Porre RJ, van der Werf W, De Deyn GB, Stomph TJ, Hoffland E. 2020. Is litter decomposition enhanced in species mixtures? A meta anlaysis. Soil Biol Biochem 145:107791. https://doi.org/ 10.1016/j.soilbio.2020.107791.

Pregitzer KS. 2002. Fine roots of trees-a new perspective. New Phytol. https://doi.org/10.1046/j.1469-8137.2002.00413_1.x/ full.

Prescott CE, Grayston SJ. 2013. Tree species influence on microbial communities in litter and soil: current knowledge and research needs. For Ecol Manage 309:19-27. https://doi. org/10.1016/j.foreco.2013.02.034.

Prieto I, Birouste M, Zamora-Ledezma E, Gentit A, Goldin J, Volaire F, Roumet C. 2017. Decomposition rates of fine roots from three herbaceous perennial species: combined effect of root mixture composition and living plant community. Plant Soil 415:359-372. 
R Core Team. 2018. R: A language and environment for statistical computing.

Reich PB, Luo Y, Bradford JB, Poorter H, Perry CH, Oleksyn J. 2014. Temperature drives global patterns in forest biomass distribution in leaves, stems, and roots. Proc Natl Acad Sci USA 111:13721-13726.

Scheibe A, Steffens C, Seven J, Jacob A, Hertel D, Leuschner C, Gleixner G. 2015. Effects of tree identity dominate over tree diversity on the soil microbial community structure. Soil Biol Biochem 81:219-227. https://doi.org/10.1016/j.soilbio.2014. 11.020 .

Scherer-Lorenzen M. 2008. Functional diversity affects decomposition processes in experimental grasslands. Funct Ecol 22:547-555.

Scherer-Lorenzen M. 2014. The functional role of biodiversity in the context of global change. In: Coomes DA, Burslem DFRP, Simonson WD, Eds. Forests and global change, . Cambridge University Press. pp 195-238.

Schimel JP, Hättenschwiler S. 2007. Nitrogen transfer between decomposing leaves of different $\mathrm{N}$ status. Soil Biol Biochem 39:1428-1436.

Schindler MH, Gessner MO. 2009. Functional leaf traits and biodiversity effects on litter decomposition in a stream. Ecology 90:1641-1649.

See CR, McCormack ML, Hobbie SE, Flores-Moreno H, Silver WL, Kennedy PG, Gessner M. 2019. Global patterns in fine root decomposition: climate, chemistry, mycorrhizal association and woodiness. Ecol Lett 22:946-953. https://doi.org/10. $1111 /$ ele.13248? af =R.

Silver WL, Miya RK. 2001. Global patterns in root decomposition: comparisons of climate and litter quality effects. Oecologia 129:407-419. https://doi.org/10.1007/ s004420100740.

Solly EF, Schöning I, Boch S, Kandeler E, Marhan S, Michalzik B, Müller J, Zscheischler J, Trumbore SE, Schrumpf M. 2014. Factors controlling decomposition rates of fine root litter in temperate forests and grasslands. Plant Soil 382:203-218.

Song X, Wang Z, Tang X, Xu D, Liu B, Mei J, Huang S, Huang G. 2020. The contributions of soil mesofauna to leaf and root litter decomposition of dominant plant species in grassland. Appl Soil Ecol 155:103651. https://doi.org/10.1016/j.apsoil. 2020.103651.

Sun T, Dong L, Zhang L, Wu Z, Wang Q, Li Y, Zhang H, Wang Z. 2016. Early stage fine-root decomposition and its relationship with root order and soil depth in a Larix gmelinii plantation. Forests 7:1-10.

Sun T, Hobbie SE, Berg B, Zhang H, Wang Q, Wang Z, Hättenschwiler S. 2018. Contrasting dynamics and trait controls in first-order root compared with leaf litter decomposition. Proc Natl Acad Sci USA 115:10392-10397.

Sun T, Mao Z, Dong L, Hou L, Song Y, Wang X. 2013. Further evidence for slow decomposition of very fine roots using two methods: Litterbags and intact cores. Plant Soil 366:633-646.
Swift MJ, Heal OW, Anderson JM. 1979. Decomposition in terrestrial ecosystems. Blackwell Scientific Publications

Tardif A, Shipley B. 2015. The relationship between functional dispersion of mixed-species leaf litter mixtures and species' interactions during decomposition. Oikos 124:1050-1057.

Tiunov AV. 2009. Particle size alters litter diversity effects on decomposition. Soil Biol Biochem 41:176-178. https://doi. org/10.1016/j.soilbio.2008.09.017.

Vesterdal L, Clarke N, Sigurdsson BD, Gundersen P. 2013. Do tree species influence soil carbon stocks in temperate and boreal forests? For Ecol Manag 309:4-18. https://doi.org/10. 1016/j.foreco.2013.01.017.

Vivanco L, Austin AT. 2006. Intrinsic effects of species on leaf litter and root decomposition: a comparison of temperate grasses from North and South America. Oecologia 150:97107.

Vivanco L, Austin AT. 2008. Tree species identity alters forest litter decomposition through long-term plant and soil interactions in Patagonia, Argentina. J Ecol 96:727-736.

Vos VCA, van Ruijven J, Berg MP, Peeters ETHM, Berendse F. 2013. Leaf litter quality drives litter mixing effects through complementary resource use among detritivores. Oecologia 173:269-280.

Wambsganss J, Beyer F, Freschet GT, Scherer-Lorenzen M, Bauhus J. 2021a. Tree species mixing reduces biomass but increases length of absorptive fine roots in European forests. J Ecol 109:2678-2691.

Wambsganss J, Freschet GT, Beyer F, Goldmann K, Prada-Salcedo LD, Scherer-Lorenzen M, Bauhus J. 2021 b. Tree species mixing causes a shift in fine-root soil exploitation strategies across European forests. Funct Ecol 35:1886-1902.

Xiong Y, Fan P, Fu S, Zeng H, Guo D. 2013. Slow decomposition and limited nitrogen release by lower order roots in eight Chinese temperate and subtropical trees. Plant Soil 363:19-31.

Zhang DQ, Hui DF, Luo YQ, Zhou GY. 2008. Rates of litter decomposition in terrestrial ecosystems: global patterns and controlling factors. J Plant Ecol 1:85-93.

Zhang X, Wang W. 2015. The decomposition of fine and coarse roots: their global patterns and controlling factors. Sci Rep 5:9940. https://doi.org/10.1038/srep09940.

Zhou S, Butenschoen O, Barantal S, Handa IT, Makkonen M, Vos V, Aerts R, Berg MP, McKie B, Van Ruijven J, Hättenschwiler S, Scheu S. 2020. Decomposition of leaf litter mixtures across biomes: The role of litter identity, diversity and soil fauna. J Ecol 108:2283-2297.

Zwetsloot MJ, Ucros JM, Wickings K, Wilhelm RC, Sparks J, Buckley DH, Bauerle TL. 2020. Prevalent root-derived phenolics drive shifts in microbial community composition and prime decomposition in forest soil. Soil Biol Biochem 145. 